\title{
PEMBINAAN PEGAWAI DALAM PELAKSANAAN TUGAS \\ DI BIRO UMUM KANTOR GUBERNUR \\ PROVINSI SUMATERA SELATAN
}

\author{
Dian Anggraini \\ Sekolah Tinggi Ilmu Administrasi (STIA) Satya Negara Palembang \\ Email : bundafira81@gmail.com
}

\begin{abstract}
The goal of this research are to see information about employee coaching duties. The population is 151 employee and the sample is 53 people that taken by stratified proportional random sampling. The instrument of this research is question with Likert scale models that had tested for validity and reliability. Data analyzed using mean score. The result of this research are the employee coacing duties Biro Umum Kantor Gubernur Provinsi South Sumatra. Stay in is Good category.
\end{abstract}

Keywords: The task of coaching employees.

\section{Pendahuluan}

Organisasi adalah suatu wadah untuk menampung inspirasi-inspirasi dari berbagai individu, organisasi ini bisa terbentuk karena adanya kesamaan latar belakang dan kesamaan dalam mencapai tujuan. Menurut Dwight Waldo (Dalam buku Ilmu Administrasi publik 2006:52) mengatakan bahwa organisasi adalah sebagai suatu struktur kewenangan dan kebiasaan dalam hubungan antara orangorang pada suatu sistem organisasi. Untuk menggerakan suatu organisasi diperlukan adanya sumber daya manusia yang berperan dan tantangan dalam pengembangan manajemen. Menurut Hasibuan (2012:224) mengatakan bahwa Sumber Daya Manusia adalah kemampuan terpadu dari daya pikir dan daya fisik yang dimliki individu. Salah satu faktor yang menyebabkan sebuah organisasi dapat sukses adalah apabila seluruh komponen organisasi tersebut berjalan dengan efektif, dengan demikian organisasi akan dapat mencapai target, hasil atau sasaran yang diinginkan.

Komponen tersebut adalah pimpinan dan pegawai. Menurut Hasibuan (2012:13) mengatakan pemimpin adalah seseorang yang dipergunakan wewenang dan kepemimpinan untuk mengarahkan orang lain serta bertanggung jawab atas pekerjaan orang dalam mencapai suatu tujuan. Sedangkan menurut Abdul rachman (1979: 123) mengatakan bahwa yang dimaksud dengan pegawai adalah mereka yang bekerja di bawah perintah orang lain untuk menerima upah sebagai imbalan jasanya. Jika pegawai telah selesai melakukan suatu pekerjaan dengan baik maka kepuasan kerja akan timbul dalam diri pegawai. Oleh karena itu pegawai secara ideal berperan aktif dan menempatkan kedudukannya sebagai 
profesional sehingga menunjang keberhasilan program pembinaan pegawai pada organisasi termasuk pegawai negeri.

Pegawai Negeri Sipil yang ditempatkan dan bekerja di lingkungan birokrasi untuk menjalankan tugas pokok dan fungsi sebagaimana telah ditetapkan. Maka dilakukan adanya pembinaan. Menunut Thoha (1989: 7) pembinaan adalah suatu proses, hasil atau pertanyaan menjadi lebih baik, dalam hal ini mewujudkan adanya perubahan, kemajuan, peningkatan, pertumbuhan, evaluasi atau berbagai kemungkinan atas sesuatu. Jadi pembinaan merupakan faktor terpenting untuk mencapai keberhasilan tujuan organisasi. Pembinaan adalah upaya untuk meningkatkan keahlian, pengetahuan, keterampilan, sikap, serta kedisiplinan dalam melaksanakan tugas. Jika tugas yang dilaksanakan agar memperoleh hasil yang baik, maka pimpinan dapat mengadakan di dalam organisasi yaitu pembinaan pegawai. Pembinaan biasanya dilaksanakan oleh pimpinan organisasi, dimana pimpinan berperan aktif di dalam organisasi. Menurut Wibowo (2012:91) mengatakan bahwa pemimpin dengan banyak pengikut dan tidak lagi diikuti. Jadi pengikut maksutnya adalah bawahan yang akan dibina kinerjanya oleh pimpinan, karena kinerja akan efektif apabila adanya melakukan pembinaan pegawai. Namun berdasarkan kenyataan di lapangan bahwa pegawai biro umum ini jarang bahkan tidak pemah mendapat pembinaan dari pimpinan dalam melaksanakan tugasnya. Implikasi ini penulis dapatkan dari wawancara dengan beberapa orang pegawai Biro Umum Kantor Gubemur Provinsi Sumatera Selatan.
Dimana adanya fenomena seperti : (1) Pimpinan jarang memberikan pengakuan dan motivasi kepada pegawai biro umum yang bekerja dengan menggunakan keterampilan (skill) dan mempunyai prestasi dalam bekerja, (2) Pimpinan kurang memberikan bimbingan terhadap pegawai biro umum sehingga kurang mengerti dalam melaksanakan tugas yang diberikan, dan (3) Pimpinan jarang mengawasi disiplin pegawai biro umum yang tidak sesuai dengan aturan yang berlaku selama bekerja. Fenomena di atas timbul dikarenakan pihak organisasi kurang memahami bagaimana Pembinaan Pelaksanaan Tugas Pegawai Biro Umum Kantor Gubemur Provinsi Sumatera Selatan. Indikator pelaksanaan tugas yang baik meliputi Pengetahuan, keterampilan, sikap/tingkah laku, serta kedisiplinan. Pengetahuan pegawai sangatlah berperan penting dalam menyelesaikan tugas, dimana tugas yang dikerjakan sesuai tujuan dari organisasi. Menurut Tanck (Dalam buku pendidikan IPS 2012:58) mengatakan bahwa pengetahuan (knowledge) di anggap sebagai hasil kerja intelektual yang dikembangkan oleh manusia melalui proses psikologisnya. pengetahuan dimiliki setiap orang mencangkup keyakinan-keyakinan dan pengalaman bekerja. Jadi pengetahuan menupakan hasil dari pemikiran seseorang, apabila seseorang tersebut dapat meningkatkan pengetahuannya maka hasil pemikiran seseorang itu akan berkembang dengan luas. Keterampilan pegawai sangatlah berdaya guna bagi kelancaran proses jalan penyelesaikan tugas, agar menjadi kreatif dan inovatif. Menurut Moenir (1995:117) mengatakan bahwa keterampilan adalah kemampuan 
melaksanakan tugas/pekerjaan dengan menggunakan anggota badan dan Jadi Moenir (1995:150) mengatakan sikap adalah suatu hasil proses rasa dan pikir mengenai obyek tertentu setelah diransang baik dari dalam maupun dari luar. Sikap atau tingkah laku adalah satu kesatuan yang terdiri dari diri individu itu sendiri yang ditunjukan terhadap pekerjaan sangatlah penting demi mencapai faktor keberhasilan organisasi kerja. Disiplin pegawai beranjak dari pandangan bahwa tidak ada manusia yang sempuma, tidak luput dari kekhilafan dan kesalahan. Disiplin dalam pelaksanaan, Moenir (1995:94) mengatakan disiplin adalah suatu bentuk ketaatan terhadap aturan, baik tertulis maupun yang telah ditetapkan. Disiplin sangat menunjang hasil kerja dan kepribadian pegawai dalam pelaksanaan tugas. peralatan kerja yang tersedia. Keterampilan lebih banyak menggunakan unsur anggota badan dari pada unsur lain.

Keterampilan menupakan karya atau keahlian seseorang dalam melakukan kegiatan bukan menggunakan pemikiran tetapi menggunakan anggota badan, sehingga pelaksanaan tugas menjadi lebih baik dan inovatif. Sikap dan tingkah laku biasanya terdapat dari pribadi individu itu sendiri.

\section{METODE PENELITIAN}

Jenis penelitian ini merupakan penelitian deskriptif. Populasi dalam penelitian ini adalah selunuh pegawai di Biro Umum Kantor Gubemur Provinsi Sumatera Selatan sebanyak 151 pegawai kecuali pimpinan. Pengambilan sampel dalam penelitian ini menggunakan teknik Proportional stratified
Random Sampling dengan menggunakan kriteria Strata populasi $\leq \mathrm{S} 1$ dan $>\mathrm{S} 1$ sehingga didapatkan hasil pengambilan sampel sebanyak 53 orang pegawai. Jenis data dalam penelitian ini adalah data primer yang artinya data diperoleh langsung dari responden. Teknik analisis data hasil penelitian ini menggunakan rumus rata-rata.

\section{HASIL PENELITIAN}

Hasil penelitian ini akan menguraikan deskripsi data tentang Pembinaan Pegawai Dalam Pelaksanaan Tugas dengan cara Pembinaan Motivasi, Bimbingan, dan Pengawasan untuk meningkatkan pengetahuan, keterampilan, sikap/tingkah laku, serta kedisiplinan pegawai. Hasil pengolahan data dilihat dari hasil rekapitulasi pembinaan pegawai dalam pelaksanaan tugas dengan cara memotivasi secara keseluruhan dimana skor tertinggi diperoleh pada aspek kedisiplinan yaitu 4,26. Kemudian disusul pada aspek keterampilan yaitu 4,16. Selanjutnya aspek pengetahuan yaitu 4,13. Dan yang terakir pada aspek yang terendah yaitu aspek sikap/tingkah laku yaitu 3,94. Berarti pembinaan memotivasi untuk meningkatkan aspek pengetahuan, keterampilan, sikap/tingkah laku serta kedisiplinan sudah terlaksana Dengan Baik $(4,12)$. Kemudian hasil pengolahan data dilihat dari hasil rekapitulasi pembinaan pegawai dalam pelaksanaan tugas dengan cara membimbing secara keseluruhan dimana skor tertinggi diperoleh pada aspek kedisiplinan yaitu 4,30. Kemudian disusul pada aspek pengetahuan yaitu 4,14. Selanjutnya aspek keterampilan yaitu 4,14. Dan yang terakir pada aspek yang terendah yaitu aspek sikap / tingkah laku yaitu 3,38. Berarti pembinaan membimbing 
untuk meningkatkan aspek pengetahuan, keterampilan, sikap/tingkah laku serta kedisiplinan sudah terlaksana Dengan Baik (3,96).

Selanjutnya hasil pengolahan data dilihat dari hasil rekapitulasi pembinaan pegawai dalam pelaksanaan tugas dengan cara mengawasi secara keselunuhan menunjukkan dimana skor tertinggi diperoleh pada aspek keterampilan yaitu 4,23. Kemudian disusul pada aspek kedisiplinan yaitu 4,09. Selanjutnya aspek sikap/tingkah laku yaitu 4,07. Dan yang terakir pada aspek yang terendah yaitu aspek pengetahuan yaitu 3,08. Berarti pembinaan mengawasi untuk meningkatkan aspek pengetahuan, keterampilan, sikap/tingkah laku serta kedisiplinan sudah terlaksana Dengan Baik $(3,86)$. Secara keseluruhan, rata-rata skor yang diperoleh telah menunjukkan bahwa pimpinan telah melakukan pembinaan pegawai dengan cara memotivasi, membimbing, dan mengawasi untuk meningkatkan pengetahuan, keterampilan, sikap/tingkah laku, dan kedisiplinan dalam pelaksanakan tugas pegawai Biro Umum. Dari hasil penelitian ini dapat disimpulkan bahwa Pembinaan Pegawai Dalam Pelaksanakan Tugas di Biro Umum Kantor Gubemur Provinsi Sumatera Selatan terlaksana Dengan Baik $(3,98)$.

\section{PEMBAHASAN}

Hasil pengolahan data penelitian menunjukkan bahwa Pembinaan Pegawai Dalam Pelaksanakan Tugas di Biro Umum Kantor Gubemur Provinsi Sumatera Selatan terlaksana secara keseluruhan berada pada kategori baik dengan rata-rata skor 3,98. Untuk lebih jelasnya berikut akan diuraikan pembahasan masingmasing indikator. Pembinaan Motivasi Pegawai
Dalam Pelaksanaan Tugas di Biro umum Kantor Gubernur Provinsi Sumatera Selatan memperoleh hasil penelitian menunjukkan bahwa Pembinaan Motivasi Pegawai Dalam Pelaksanaan Tugas terlaksana dengan baik. Data menunjukkan bahwa aspek pengetahuan, keterampilan, sikap/tingkah laku, dan kedisiplinan. Hal ini terlihat dari pelibatan pimpinan dan pegawai dalam pengembangkan pengetahuan dan pengembangan keterampilan, memberikan sikap/tingkah laku dan kedisiplinan pada organisasi dalam melaksanakan tugas yang baik terhadap organisasi. Wursanto (1989:131) mengatakan motivasi timbul karena dua faktor, faktor intrinsik adalah faktor dalam diri manusia dan faktor ekstrinsik adalah fakor dari luar diri manusia. Jadi dapat disimpulkan setelah melihat hasil penelitian dibandingkan dengan pendapat para ahli bahwa pengetahuan, keterampilan, sikap/tingkah laku, dan kedisiplinan pegawai terbentuk dari diri pegawai itu sendiri, maka ada gunanya pimpinan sebagai motivator untuk mengarahkan dan mendorong pegawai agar dapat meningkatkan dan mengembangkan dirinya dalam melaksanakan tugas. Untuk itu perlu adanya usaha pimpinan untuk mempertahankan dan meningkatkan pembinaan motivasi kearah yang lebih baik lagi, sehingga dapat tercipta pembinaan motivasi pegawai yang mampu mendukung pencapaian tujuan organisasi. Sedangkan Pembinaan Bimbingan Pegawai Dalam Pelaksanaan Tugas di Biro umum Kantor Gubernur Provinsi Sumatera Selatan memperoleh hasil penelitian penunjukkan bahwa Pembinaan Bimbingan Pegawai Dalam Pelaksanaan Tugas terlaksana dengan baik. Data menunjukkan bahwa 
aspek pengetahuan, keterampilan, sikap/tingkah laku, dan kedisiplinan. Hal ini terlihat dari pelibatan pimpinan dan pegawai dalam pengembangkan pengetahuan dan pengembangan keterampilan, memberikan sikap/tingkah laku dan kedisiplinan pada organisasi dalam melaksanakan tugas yang baik terhadap organisasi. Menurut Dewa dan Nila (2008:1) mengatakan bahwa bimbingan adalah suatu proses pemberian bantuan kepada individu yang dilakukan secara berkesinambungan, agar individu tersebut dapat memahami dirinya sendiri. Jadi dapat disimpulkan setelah melihat hasil penelitian dibandingkan dengan pendapat para ahli bahwa pengetahuan, keterampilan, sikap/tingkah laku, dan kedisiplinan pegawai perlu adanya pemberian bimbingan oleh pimpinan, dimana didalam diri pegawai perlu adanya bantuan dari pimpinan dalam melaksanakan tugas. Dimana diantara beberapa pegawai terdapat rasa tidak percaya diri atau kurangnya informasi untuk mengembangkan diri. Maka perlunya pimpinan memberikan bantuan dan pelatihan kepada pegawai guna membentuk cara pandang dan kerja pegawai yang baik. Untuk itu perlu adanya pimpinan untuk usaha mempertahankan dan meningkatkan pembinaan Bimbingan kearah yang lebih baik lagi, sehingga dapat tercipta pembinaan bimbingan yang mampu mendukung pencapaian tujuan organisasi. Dan yang terakhir Pembinaan Pengawasan Pegawai Dalam Pelaksanaan Tugas di Biro umum Kantor Gubemur Provinsi Sumatera Selatan memperoleh hasil penelitian menunjukkan bahwa Pembinaan Pengawasan Dalam Pelaksanaan Tugas Pegawai dikategorikan dengan baik. Menurut Soekamo dalam Mukti (2004:1) menjelaskan bahwa pengawasan adalah suatu proses yang menentukan tentang apa yang harus dikerjakan, agar apa yang diselenggarakan sejalan dengan rencana. Sedangkan menurut Yuniarsih dan Suwatno (2011:93) fungsi pengawasan SDM adalah proses evaluasi untuk mengukur kesesuaian dan kelancaran pelaksanaan kegiatan. Jadi dapat disimpulkan setelah melihat hasil penelitian dibandingkan dengan pendapat para ahli bahwa pengetahuan, keterampilan, sikap/tingkah laku, dan kedisiplinan pegawai perlu adanya pengawasan oleh pimpinan, dimana pimpinan bisa melihat potensi dan kinerjanya pada pelaksanaan tugas dan membenah diri pegawai ke hal yang lebih baik dan menunjang perkembangan pegawai sesuai tujuan organisasi. Hal ini berarti pimpinan telah perlu meningkatkan kembali pembinaan pengawasan pada pegawai terkait dengan pelaksanakan tugas meskipun masih dalam kategori cukup baik. Secara umum, Pembinaan Pegawai Dalam Pelaksanaan Tugas dapat dikategorikan terlaksana dengan baik. Adanya perbedaan pengamatan awal dengan hasil penelitian, ini terjadi barang kali alat pengumpulan data belum valid dan belum tentu kebenaranya, makanya peneliti melakukan kegiatan penelitian guna mendapatkan hasil yang baik dan sesuai dengan tujuan. Untuk itu perlu adanya usaha pimpinan untuk mempertahankan dan meningkatkan pembinaan pelaksanaan tugas pegawai kearah yang lebih baik lagi, sehingga dapat tercipta hasil kerja yang mampu mendukung pencapaian tujuan organisasi

\section{KESIMPULANDANSARAN}

\section{Kesimpulan}


Berdasarkan hasil penelitian yang telah dikemukakan pada bab sebelumnya, mengenai Pembinaan Pegawai Dalam Pelaksanaan Tugas di Biro Umum pada Kantor Gubemur Provinsi Sumatera Selatan untuk meningkatkan pengetahuan, keterampilan, sikap/tingkah laku, dan kedisiplinan dapat ditarik terakhir Pembinaan pegawai dalam pelaksanakan tugas dengan cara mengawasi Pegawai terlaksana dengan baik $(3,86)$. Secara umum dapat disimpulkan bahwa Pembinaan Pegawai Dalam Pelaksanaan Tugas di Biro Umum Kantor Gubemur Provinsi Sumatera Selatan dapat dikategorikan terlaksana dengan baik $(3,98)$. Untuk itu perlu kiranya bagi pimpinan untuk dapat mempertahankan dan meningkatkan pembinaan pelaksanaan tugas pegawai agar mendapat hasil yang baik. kesimpulan bahwa Pembinaan pegawai dalam pelaksanaan tugas dengan cara memotivasi Pegawai terlaksana dengan baik (4,12). Sedangkan Pembinaan pegawai dalam pelaksanakan tugas dengan cara membimbing pegawai terlaksana dengan baik $(3,96)$.

\section{Saran}

Berdasarkan kesimpulan yang telah dikemukakan di atas, dapat di kemukakan beberapa saran bagi Pimpinan Biro umum diharapkan untuk dapat meningkatkan pembinaan dalam pelaksanaan tugas pegawai Biro umum. Upaya yang dapat dilakukan pimpinan untuk meningkatkan pembinaan tersebut dapat dilakukan dengan menambah pengetahuan, keterampilan, sikap/tingkah laku, dan kedisiplinan yang dapat menyalurkan aspirasi warga organisasi tenutama sesama rekan kerja didalam organisasi. Sedangkan bagi pemerintah daerah agar lebih giat memberikan penyuluhan kepada organisasi dalam menambah pengetahuan, keterampilan, sikap/tingkah laku, dan kedisiplinan. Untuk itu diharapkan kerja sama yang baik antar organisasi dalam pengembangan hasil kerja pegawai di masa yang akan datang. Sertabagi organisasi diharapkan untuk lebih berperan aktif dalam penyelenggaraan pendidikan di organisasi. Cara yang bisa dilakukan seperti menyalurkan aspirasi mereka bersifat membangun terhadap organisasi.

\section{DAFTAR PUSTAKA}

Fathoni, Abdurrahmat. H. (2006). Organisasi dan Manajemen Sumber Daya Manusia. Jakarta:PT. Rineka Cipta.

Ibrahim, Adam. Indrawijaya. H \& Pranoto, Juni.

H. (2011). Strategi Pembaharuan Administrasi dan Manajemen Publik. Bandung: Alfabeta.

Hasibuan, S.P Malayu(2012).

Manajemen Sumber Daya Manusia. Jakarta:PT. Raja GrafindoPersada.

Moenir, H.A.S. (1995). Manajemen Pelayanan Umum di Indonesia. Jakarta : PT. Bumi Aksara.

Sapriya. (2012). Pendidikan IPS Konsep dan Pembelajaran. Bandung : PT. Remaja Rosdakarya.

Sugiyono. (2012). Metode Penelitian Administrasi. Bandung: Alfabeta. 
Thoha, Miftah. (1997). Pembinaan Organisasi

Proses Diagnosa dan Interval. Jakarta : PT.

Raja Grafindo Persada.

Wibowo. (2012). Manajemen Kinerja. Jakarta :

PT. Raja Grafindo Persada. 